\title{
PENGARUH MODEL PEMBELAJARAN PEMBELAJARAN BERBASIS MASALAH BERBANTUAN MEDIA KONKRIT TERHADAP HASIL BELAJAR MATEMATIKA DITINJAU DARI DISPOSISI MATEMATIKA
}

\author{
N.W. Sudiasih ${ }^{1}$, N. Dantes ${ }^{2}$, Sariyasa $^{3}$ \\ Program Studi Pendidikan Dasar, Program Pascasarjana Universitas Pendidikan \\ Ganesha Singaraja, Indonesia \\ e-mail: wayan.sudiasih@pasca.undiksha.ac.id, dantes@pasca.undiksha.ac.id, \\ sariyasa@pasca.undiksha.ac.id)
}

\begin{abstract}
Abstrak
Penelitian ini bertujuan untuk mengetahui pengaruh model pembelajaran problem based learning (PBL) berbantuan media konkrit terhadap hasil belajar matematika ditinjau dari disposisi matematika siswa kelas III di Gugus VI Sukawati Tahun Pelajaran 2016/2017. penelitian ini merupakan penelitian eksperimen semu. Rancangan penelitian yang digunakan adalah design dengan rancangan faktorial $2 \times 2$. Populasi dalam penelitian ini adalah seluruh siswa kelas III SD yang ada di Gugus VI Kecamatan Sukawati yang terdiri dari 278 siswa. Sebanyak 40 siswa dipilih sebagai sampel yang ditentukan dengan teknik group random sampling. Data disposisi Matematika dikumpulkan dengan kuesioner dan hasil belajar Matematika menggunakan tes pilihan ganda. Data dianalisis dengan menggunakan analisis Anava dua jalan berbantuan SPSS 17.00 for windows. Hasil Penelitian menunjukkan bahwa: Pertama, terdapat perbedaan hasil belajar matematika antara kelompok siswa yang mengikuti model pembelajaran berbasis masalah berpendekatan saintifik dengan bantuan media konkrit dan kelompok siswa yang mengikuti pembelajaran konvensional berpendekatan saintifik. Kedua, terdapat pengaruh interaksi antara model pembelajaran dan disposisi matematika terhadap hasil belajar matematika. Ketiga, pada siswa yang memiliki disposisi matematika tinggi, terdapat perbedaan hasil belajar matematika antara kelompok siswa yang mengikuti model pembelajaran Berbasis Masalah berpendekatan saintifik berbantuan media konkrit dan kelompok siswa yang mengikuti model pembelajaran konvensional berpendakatan saintifik. Kempat, pada siswa yang memiliki disposisi matematika rendah, terdapat perbedaan yang signifikan hasil belajar matematika antara kelompok siswa yang mengikuti model pembelajaran Berbasis Masalah berpendekatan saintifik berbantuan media konkrit dan kelompok siswa yang mengikuti model pembelajaran konvensional berpendekatan saintifik.
\end{abstract}

Kata Kunci: Disposisi Matematika, Hasil Belajar Matematika, Media Konkrit, Pembelajaran Berbasis Masalah

\begin{abstract}
This study aims to determine the magnitude of the influence of problem based learning (PBL) learning models assisted with concrete media on mathematics learning outcomes in terms of mathematical disposition of class III students in Cluster Sukawati Academic Year 2016/2017. This type of research is quasi-experimental research. The study design used a $2 \times 2$ factorial design. The population in this study were all class III elementary schools in the Cluster VI of Sukawati District which consisted of 278 students. A total of 40 students were selected as samples determined by group random sampling technique. Mathematical disposition data is collected by questionnaire and Mathematics learning outcomes using multiple choice tests. Data were analyzed using analysis of two-way Anava assisted SPSS 17.00 for windows. Research results show that: First, there are differences in mathematics learning outcomes between groups of students who follow a problem-based learning model with scientific approach assisted by concrete media an groups of students who follow conventional learning with scientific approach. Second,
\end{abstract}


there is a interaction between the learning model and the disposition of mathematics on the learning outcomes of mathematics. Third, in students who have high mathematical dispositions, there are differences in mathematics learning outcomes between groups of students who follow the Problem Based Learning learning model with scientific approach assisted with concrete media and groups of students who follow conventional learning models with scientific approach. Fourth, in students who have low mathematical dispositions, there are significant differences in mathematics learning outcomes between groups of students who follow the Problem Based Learning learning model with scientific approach assisted with concrete media and groups of students who follow conventional learning models with scientific approach.

Keywords: disposition of mathematics, mathematics learning outcomes, concrete media, problem based learning 


\section{PENDAHULUAN}

Materi pada mata pelajaran matematika adalah konsep yang bersifat abstrak. Sedangkan dalam proses pembelajaran, guru menggunakan metode ceramah dalam menyampaikan materi tersebut. Metode ceramah untuk menyampaikan konsep matematika yang bersifat abstrak membuat peserta didik sulit memahami materi. Hal ini disebabkan karena peserta didik yang masih berfikir konkret. Akibatnya, matematika menjadi salah satu mata pelajaran yang dianggap sulit karena capaian hasil belajar peserta didik masih kurang.

Melihat permasalahan ini, perlu dilakukan perbaikan agar proses pembelajaran menjadi lebih baik sehingga dapat meningkatkan kualitas pembelajaran khususnya pelajaran matematika. Pembelajaran perlu dirancang dan dilaksanakan sesuai dengan karakteristik peserta didik. menumbuhkan minat peserta didik dalam mengikuti pembelajaran.

Sebagai pendidik, guru perlu memilih model yang tepat untuk

menyampaikan sebuah konsep kepada anak didiknya. Untuk mencapai hasil belajar secara optimal, upaya yang dapat dilakukan seorang guru adalah menggunakan model yang sesuai dalam menyampaikan materi kepada peserta didik

Menyikapi permasalahan yang terjadi dilapangan yang sudah tidak menjadi rahasia umum lagi, maka dari itu peran guru akan menjadi pusat perhatian dari keberhasilan pembelajaran dalam dunia pendidikan. Keberhasilan pembelajaran dalam dunia pendidikan dapat terukur dari prestasi belajar siswa. Prestasi belajar merupakan nilai yang menunjukkan kualitas keberhasilan dimana keberhasilan itu diperoleh siswa dengan mengikuti evaluasi yang diselenggarakan oleh guru maupun sekolah.

Untuk menciptakan situasi dan kondisi kelas yang menyenangkan maka guru harus berperan sebagai seorang fasilitator dan motivator untuk mengoptimalkan belajar siswa sehingga diperoleh prestasi belajar yang bagus dan memuaskan. Untuk dapat memotivasi siswa lebih aktif dan lebih berani dalam pelajaran matematika, guru hendaknya menggunakan model pembelajaran yang menarik dan mudah dipahami siswa.

Proses pembelajaran matematika di sekolah-sekolah belum dapat berlangsung sesuai dengan tuntutan kurikulum. Kegiatan pembelajaran yang berlangsung masih berpusat pada guru. Sebagai salah satu bukti, hasil observasi di SD Gugus VI Sukawati Kabupaten Gianyar menunjukkan bahwa pembelajaran Matematika yang dilaksanakan belum optimal dan tidak sesuai tuntutan kurikulum. Hal ini terlihat saat kegiatan inti pembelajaran guru tidak melibatkan peserta didik mencari informasi mengenai topik yang akan dipelajari melainkan guru yang memberi informasi, sehingga mereka tidak mengetahui cara mendapatkan konsep-konsep yang baru. Pada ini pembelajaranpun terlihat bahwa siswa tidak mempersentasikan tugas yang telah didiskusikan, melainkan hanya mengumpulkannya pada guru, dan gurulah yang membacakan hasil diskusi yang telah dikerjakan siswa.

Menurut Katz sebagaimana dikutip dalam Mahmudi (2010: 5) mendefinisikan disposisi sebagai kecenderungan untuk berperilaku secara sadar (consciously), teratur (frequently), dan sukarela (voluntary) untuk mencapai tujuan tertentu. Perilaku-perilaku tersebut diantaranya adalah percaya diri, gigih, ingin tahu, dan berpikir fleksibel. Dalam konteks matematika, disposisi matematis (mathematical disposition) berkaitan dengan bagaimana peserta didik menyelesaikan masalah matematis: apakah percaya diri, tekun, berminat, dan berpikir fleksibel untuk mengeksplorasi berbagai alternatif penyelesaian masalah. Dalam konteks pembelajaran, disposisi matematis berkaitan dengan bagaimana peserta didik bertanya, menjawab pertanyaan, mengkomunikasikan ide-ide 
matematis, bekerja dalam kelompok, dan menyelesaikan masalah.

Kilpatrick, Swafford, dan Findel (2001

131) menyatakan bahwa disposisi matematis peserta didik dapat berkembang ketika peserta didik mempelajari aspek

kompetensi lainnya. Salah satunya adalah aspek yang berkaitan dengan hasil belajar, sehingga disposisi matematis peserta didik merupakan faktor utama dalam menentukan kesuksesan pendidikan peserta didik. Oleh karena itu disposisi matematis merupakan aspek yang berkaitan dengan kemampuan pemecahan masalah dalam pembelajaran matematika. Dapat dipahami bahwa disposisi matematis sangat menunjang keberhasilan belajar matematika, peserta

didik memerlukan disposisi matematis untuk bertahan dalam menghadapi masalah, mengambil tanggung jawab dalam belajar, dan mengembangkan kebiasaan kerja yang baik dalam matematika, karakteristik demikian penting dimiliki peserta didik (Mahmudi, 2010: 2). Seorang yang memiliki desposisi tinggi akan memiliki hasl belajar yang lebih baik dari pada sesorang yang memiliki desposisi rendah. Hal ini disebabkan sesorang yang memiliki desposisi tinggi akan memiliki kemampuan belajar yang baik sehingga akan berpengaruh pada hasil belajar matematika siswa tersebut.

Berdasarkan latar belakang tersebut, perlu diadakan penelitian dengan judul: "Pengaruh Model Pembelajaran PBL Berbantuan Media Konkrit Terhadap Hasil Belajar Matematika Ditinjau dari Disposisi Matematika Siswa Kelas III di Gugus VI Sukawati Tahun Pelajaran 2016/2017".

\section{METODE PENELITIAN}

Jenis penelitian yang dilakukan adalah penelitian eksperimen semu (quasi experimental research) karena penelitian yang di lakukan ini tidak mungkin untuk meneliti semua variabel bebas yang mempengaruhi variabel

keterbatasan waktu.

$$
\text { terikat dikarenakan }
$$

Berdasarkan jenis penelitian tersebut di atas, maka desain penelitian atau rancangan penelitian yang digunakan dalam penelitian ini adalah Populasi dalam penelitian ini adalah seluruh kelas III SD yang ada di Gugus VI Kecamatan Sukawati. Adapun yang dimaksud SD Gugus VI Kecamatan Sukawati, yaitu SDN

1 Batubulan, SDN 2 Batubulan, SDN 3 Batubulan, SDN 5 Batubulan, SDN 6 Batubulan, dan SDN 7 Batubulan.

Pengambilan sampel dalam penelitian ini dilakukan dengan teknik random sampling atau sampling acak. Pada teknik acak ini, secara teoritis, semua anggota dalam populasi mempunyai kesempatan yang sama untuk dipilih menjadi sampel, sehingga pengundian dilakukan untuk mengabil sampel. Dalam penelitian ini yang diacak adalah kelas, bukan siswa dalam kelas. Dalam proses pengundian tersebut akan dipilih dua kelas eksperimen dan dua

kelas kontrol. Kelas yang digunakan sebagai sampel, terlebih dahulu dilakukan uji kesetaraan dengan menggunakan nilai ulangan akhir semester. Menggunakan uji analisis varians satu jalur (ANAVA A). Uji anava satu jalur, uji kesetaraan juga dilakukan dengan menggunakan bantuan SPSS 20 for windows dengan signifikansi $5 \%$ untuk memperkuat hasil uji kesetaraan yang diperoleh. Kriteria pengujian, jika Fhitung > Ftab, maka $\mathrm{Ho}$ ditolak dan $\mathrm{H}_{1}$ diterima, sehingga kelas tidak setara. Jika Fhitung $\leq$ Ftab, maka $\mathrm{Ho}$ diterima dan $\mathrm{H}_{1}$

ditolak sehingga kelas setara.

Jika sampel yang diuji terbukti setara, maka dilakukan pengundian lagi untuk menentukan kelas eksperimen dan kelas kontrol. Setelah dilakukan sampling, kemudian menentukan jumlah siswa yang mempunyai gaya kognitif disposisi matemataika dan jumlah siswa yang mempunyai gaya kognitif disposisi matematika baik pada kelompok eksperimen ataupun kontrol. Teknisnya, pertama skor yang diperoleh oleh siswa dari jawaban kuesioner disposisi matemataika dilakukan perangkingan yang dilakukan terhadap kelompok tinggi dan kelompok rendah berdasarkan skor yang diperoleh dengan ketentuan bahwa sebanyak $33 \%$ sebagai kelompok bawah 
dan $33 \%$ dari kelompok tinggi. Jumlah dari keseluruhan tersebut kemudian dijadikan sebagai subjek penelitian (Rasyid, 2007). ditetapkan dalam penelitian ini berupa model PBL berpendekatan saintifik berbantuan media konkret dan model pembelajaran konvensional berpendekatan saintifik. Variabel terikat dalam penelitian ini adalah hasil belajar matematika. Variabel moderator yang ditetapkan dalam penelitian ini adalah disposisi matematika.

Dalam penelitian ini digunakan dua metode analisis yaitu analisis statistic deskriftif dan analisis varian (ANAVA) dua jalur. Teknik analisis deskriptif yaitu statistik yang digunakan untuk menggambarkan atau menganalisis suatu statistik hasil penelitian tetapi tidak digunakan untuk generalisasi/inferensi. Teknik analisis ini digunakan untuk mengetahui tinggi rendahnya kualitas dari hasil belajar Matematika siswa. Analisis deskriptif yang digunakan adalah mean, median, modus, dan standar deviasi. Untuk menentukan tinggi rendahnya kualitas hasil belajar Matematika, skor rata-rata (mean) tiap-tiap variabel dikonversikan dengan menggunakan kriteria rata-rata ideal (Xi) dan standar deviasi ideal (SDi). Sebelum melakukan
Pada penelitian ini terdapat tiga variabel yaitu variabel bebas, variabel terikat, dan variabel moderator. Variabel bebas yang analisis data, maka data yang diperoleh diuji asumsinya terlebih dahulu yaitu uji normalitas dan homogenitas varians.

Uji hipotesis dalam penelitian ini menggunakan Analisis Varian (ANAVA) dua jalur. Maka dari itu, dilakukan uji prasyarat karena ANAVA dua jalur merupakan salah satu bentuk analisis statistik parametrik. Candiasa (2010:220) mengungkapkan sebelum analisis statistik parametrik dilakukan, perlu adanya pemenuhan beberapa asumsi antara lain data berdistribusi normal dan memiliki sebaran data yang homogen. Sehingga, uji prasyarat yang dilakukan terdiri dari uji normalitas sebaran data dan uji homogenitas varian.

Analisis statistik yang digunakan untuk menguji hipotesis penelitian pertama dan kedua adalah ANAVA dua jalur. Jika hipotesis kedua signifikan atau $\mathrm{Ho}$ ditolak, yang artinya terdapat interaksi antara model discovery learning dengan kemampuan berpikir kritis dalam pengaruhnya terhadap hasil belajar Matematika siswa, maka akan dilakukan uji untuk hipotesis 3 dan 4.

\section{HASIL PENELITIAN DAN PEMBAHASAN}

Masing-masing kelompok dari kedelapan kelompok distribusi disajikan dengan cara menyajikan rata-rata sebagai ukuran pemusatan, standar deviasi sebagai ukuran penyebaran, tabel frekuensi, dan histogram. Rekapitulasi hasil perhitungan skor keempat variabel dapat dilihat pada pada Tabel 01 berikut.

Tabel 01 Hasil Perhitungan Skor Hasil Belajar Matematika

\begin{tabular}{|l|r|r|r|r|r|r|r|r|}
\hline Statistik & \multicolumn{1}{|c|}{ A1 } & \multicolumn{1}{c|}{ A2 } & \multicolumn{1}{c|}{ B1 } & B2 & A1B1 & A1B2 & A2B1 & A2B2 \\
\hline Subyek (N) & 40 & 40 & 40 & 40 & 20 & 20 & 20 & 20 \\
\hline Mean & 15,98 & 13,02 & 15,20 & 13,80 & 18,35 & 13,60 & 12,05 & 14,8 \\
\hline Median & 16,5 & 13 & 16 & 14 & 18 & 14 & 12 & 14 \\
\hline Mode & 18 & 11 & 18 & 14 & 18 & 14 & 11 & 14 \\
\hline Std. Deviation & 2,98 & 2,45 & 3,61 & 2,31 & 1,31 & 2,16 & 2,04 & 2,49 \\
\hline Variance & 8,90 & 6,03 & 13,04 & 5,34 & 1,71 & 4,67 & 4,16 & 6,21 \\
\hline Range & 10 & 9 & 11 & 9 & 4 & 7 & 7 & 9 \\
\hline Minimum & 10 & 9 & 9 & 9 & 16 & 10 & 9 & 9 \\
\hline Maximum & 20 & 18 & 20 & 18 & 20 & 17 & 16 & 18 \\
\hline Sum & 639 & 521 & 608 & 552 & 367 & 272 & 241 & 280 \\
\hline
\end{tabular}




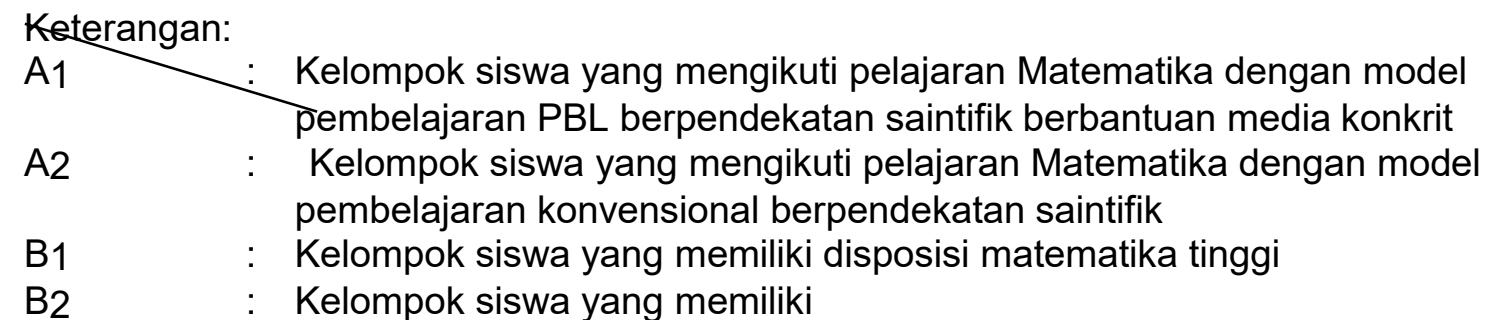

disposisi matematika rendah

A1B1

A1B2

A2B2 : Kelompok siswa yang

Kelompok siswa yang memiliki disposisi matematika tinggi

yang mengikuti pelajaran

Matematika dengan

model pembelajaran

konvensional

berpendekatan saintifik memiliki disposisi

matematika rendah yang

mengikuti pelajaran

dengan model

pembelajaran

konvensional

berpendekatan saintifik

Berdasarkan hasil pengujian hipotesis,terlihat bahwa keempat hipotesis yang diajukan pada penelitian ini telah berhasil menolak hipotesis nol, rincian hasil hipotesis tersebut sebagai berikut.

Pertama, hasil uji hipotesis pertama telah berhasil menolak Ho dan menerima $\mathrm{H}$ 1, yang berarti bahwa ada perbedaan hasil belajar Matematika antara siswa yang belajar dengan model pembelajaran PBL berpendekatan saintifik berbantuan media konkrit dengan siswa yang belajar dengan model pembelajaran konvensional berpendekatan saintifik di kelas III di Gugus VI Sukawati yang dijadikan sampel. Skor rata-rata hasil belajar Matematika siswa yang mengikuti pelajaran dengan model pembelajaran $P B L$ berbantuan media konkrit $=15,98$ dan rata-rata skor hasil belajar Matematika siswa yang mengikuti pelajaran dengan model pembelajaran konvensional $=13,03$ Sehingga secara keseluruhan, hasil belajar Matematika siswa yang mengikuti pelajaran dengan model pembelajaran PBL berpendekatan saintifik berbantuan media konkrit lebih baik daripada model pembelajaran

konvensional berpendekatan saintifik.

Hasil uji hipotesis tersebut menunjukkan bahwa model pembelajaran $P B L$ berpendekatan saintifik berbantuan media konkrit lebih unggul dalam meningkatkan hasil belajar Matematika daripada model pembelajaran konvensional berpendekatan saintifik. Keunggulan pendekatan model pembelajaran $\mathrm{PBL}$ berpendekatan saintifik berbantuan media konkrit juga dibuktikan dengan hasil penelitian Adesta yang berjudul " Pengaruh Model Pembelajaran PBL Terhadap Hasil belajar Matematika Peserta Didik Di Kelas IV Min Bandar Lampung" Pada Tahun 2017 memperoleh

hasil bahwa terdapat pengaruh model pembelajaran PBL terhadap hasil belajar matematika peserta didik kelas IV MIN 11 Bandar Lampung.

Model pembelajaran berbasis masalah memberikan suasana yang berbeda, model pembelajaran berbasis masalah dapat memberikan dampak pada suasana kelas yang sedikit gaduh. Hal ini dikarenakan siswa berdiskusi dengan kelompoknya dalam memecahkan suatu masalah. Pada saat guru menjelaskan siswa tidak hanya duduk diam 
mendengarkan penjesan guru, mealinkan siswa aktif berdiskusi dalam pemecahkan masalah dengan bim bingan guru sehingga siswa dapat berkembang dalam memecahkan masalah, serta dapat memahami pelajaran dengan baik sehingga hasil belajarnya pun bisa lebih meningkat.

Dengan bantuan media konkret dalam pembelajaran matematika dapat memberikan gambaran secara jelas kepada siswa sehingga siswa merasa semangat dan termotivasi dalam pembelajaran matematika. Ciri media konkret adalah benda asli benda dalam kadaan utuh, dapat dioperasikan, hidup dan nyata, dalam ukuran yangsebenarnya dan dapat dikenali sebagaimana ujud aslinya. Dengan menggunakan media nyata siswa dapat menggunakan berbagai indera untuk mempelajari suatu objek. Dengan menggunakan media konkret siswa dapat melihat, meraba, mencium, bahkan merasakan objek yang tengah dipelajari.

Pembelajaran Konvensional, cenderung hanya guru yang berperan aktif, siswa hanya sebagai pendengar saja sehingga pembelajaran terkesan pasif. Hal ini menyebabkan siswa kurang termotivasi dalam belajar, kurang inisiatif dan kurangnya kreativitas siswa. Pembelajaran konvensional lebih menekankan pada pembelajaran yang terjadi hanya satu arah (teacher centred) tidak multi arah.

Berdasarkan paparan di atas, tampak jelas bahwa pembelajaran PBL berpendekatan saintifik berbantuan media konkrit lebih baik diterapkan untuk siswa daripada model pembelajaran konvensional berpendekatan saintifik karena dengan pembelajaran PBL berpendekatan saintifik berbantuan media konkrit semua indra siswa terlibat dalam proses pembelajaran. Oleh karena itu, hasil belajar siswa yang mengikuti pelajaran dengan model pembelajaran PBL berpendekatan saintifik berbantuan media konkrit pada pembelajaran Matematika lebih baik daripada siswa yang mengikuti pelajaran dengan menggunakan model pembelajaran konvensional berpendekatan saintifik.

Kedua, hasil uji hipotesis kedua berhasil menolak Ho dan menerima $\mathrm{H} 1$. Ini berarti ada pengaruh interaksi antara model pembelajaran dan disposisi matematika terhadap hasil belajar Matematika yang dijadikan sampel penelitian.

Untuk siswa yang memiliki disposisi matematika tinggi, skor rata-rata hasil belajar Matematika siswa yang mengikuti pelajaran dengan model pembelajaran PBL berbantuan media konkrit $=18,35$ dan skor rata-rata hasil belajar Matematika siswa yang mengikuti pelajaran dengan model pembelajaran konvensional $=12,05$ sehingga dapat disimpulkan bahwa untuk siswa yang memiliki disposisi matematika tinggi, hasil belajar Matematika siswa yang mengikuti pelajaran dengan model pembelajaran PBL berpendekatan saintifik berbantuan media konkrit lebih baik daripada siswa yang mengikuti pelajaran dengan model pembelajaran

konvensiona

I berpendekatan saintifik.

Selanjutnya, untuk siswa yang memiliki disposisi matematika rendah, skor ratarata hasil belajar Matematika siswa yang mengikuti pelajaran dengan model pembelajaran PBL berbantuan media konkrit $=13,60$ dan skor rata-rata hasil belajar Matematika untuk siswa yang memiliki disposisi matematika rendah siswa yang mengikuti pelajaran dengan model pembelajaran konvensional $=14,80$ sehingga hasil belajar Matematika siswa yang memiliki disposisi matematika rendah siswa yang mengikuti pelajaran dengan model pembelajaran konvensional lebih baik daripada siswa yang memiliki disposisi matematika rendah siswa yang mengikuti pelajaran dengan model pembelajaran PBL berbantuan media konkrit.

Disposisi matematika merupakan dedikasi yang kuat pada diri siswa untuk belajar matematika. Dedikasi tersebut berupa apresiasi fositip siswa terhadap matematika berupa 1. Kepercayaan diri, 2 . Fleksibilitas dalam menyelidiki gagasan matematik, 3.Tekun dalam mengerjakan tugas matematika, 4. Mempunyai minat belajar dan rasa keingitahuan yang tinggi terhadap persoalan matematika. Disposisi 
matematika sangat penting dalam dunia pendidikan yang modern ini karena disposisi matematika mengacu pada individu dalam menghadapi pembelajaran matematika, dengan jenis pola prilaku dan kebiasaan kognitip matematika tertentu. Peserta didik yang memiliki disposisi yang positif dan produktif dalam belajar matematika biasanya memiliki keinginan untuk belajar dan tidak mudah menyerah ketika menghadapi permasalahan yang muncul dalam prosesnya. Dengan demikian siswa dapat mengembangkan kemandirian belajar yang menumbuhkan kemauan untuk belajar sepanjang hayat. Sehingga dalam pembelajarn dikelas siswa akan lebih aktif dan antusias dalam memecahkan permasalahan didalam belajar, keingintahuan, kesadaran, dan minat yang kuat pada diri siswa untuk belajar matematika sehingga dalam proses pembelajaran siswa tertarik untukmemecahkan masalah dan selalu melibatkan dirinya dalam mencari solusi permasalahan masalah yang diberikan pada saat siswa belajar.

Disposisi matematika siswa dikatakan baik jika siswa tersebut menyukai masalah-masalah yang merupakan tantangan serta melibatkan dirinya secara langsung dalam menemukan/menyelesaikan masalah. Selain itu siswa merasakan dirinya mengalami proses belajar saat menyelesaikan tantangan tersebut. Disposisi matematika merupakan salah satu keberhasilan belajar siswa. Maka hasil belajar matematika akan dipengaruhi oleh disposisi tinggi dan disposisi rendah matematika.

Pada sudut pandang yang berbeda pembelajaran konvensional sangat bergantung pada kemampuan guru sebagai satu-satunya sumber belajar dan kurang memberikan kesempatan pada siswa untuk mengeksplorasi diri. Hal ini berakibat pada terpendamnya daya nalar siswa. Pembelajaran konvensional ditandai dengan guru mengajar lebih banyak mengajarkan konsep-konsep bukan kompetensi, tujuannya adalah siswa mengetahui sesuatu bukan untuk mampu untuk melakukan sesuatu dan pada saat proses pembelajaran siswa lebih banyak mendengarkan. Hal ini menunjukkan bahwa pembelajaran konvensional lebih banyak didominasi gurunya sebagai pentransfer ilmu, sementara siswa lebih pasif sebagai penerima ilmu. Maka dari itu, pembelajaran konvensional meyebabkan siswa tidak dapat mengembangkan pemikiran dan cenderung membuat siswa sebagai penerima informasi, bukan aktif mencari informasi.

Temuan dalam penelitian ini sejalan dengan penelitian yang dilakukan oleh Pratiwi yang berjudul "Analisis Kemampuan Pemecahan Masalah Berdasarkan Disposisi Matematic Peserta Didik Dalam Setting Model Anchored Instruction" pada Tahun 2016 diperoleh simpulan bahwa pembelajaran dalam seting model Anchored Instruction berkualitas dengan perencanaan pembelajaran dalam kriteria baik, pelaksanaan pembelajaran dalam kriteria sangat baik, dan penilaian hasil pembelajaran menunjukkan lebih dari $75 \%$ peserta didik memenuhi kriteria ketuntasan minimal (KKM) yang ditetapkan. Penilaian perencanaan pembelajaran terdiri dari penilaian penggalan silabus dan RPP. Penilaian penggalan silabus diperoleh skor akhir 20 dengan kriteria baik dan untuk penilaian RPP diperoleh skor akhir 42,3 dengan kriteria sangat baik. Hal ini menunjukkan perencanaan pembelajaran sudah terlaksana dengan baik yang berarti penggalan silabus dan RPP yang telah dibuat dalam kriteria baik sehingga layak digunakan pada pembelajaran dalam setting model Anchored Instruction. Berdasarkan hasil penelitian di atas tentang PBL dan perbedaa model pembelajaran yang digunakan, menunjukkan arah yang berlawanan. Siswa yang memiliki disposisi tinggi diduga akan memiliki hasil matematika yang lebih tinggi apabila mengikuti pembelajaran berbasis masalah. Sebaliknya, siswa yang memiliki disposisi rendah hasil belajarnya akan lebih rendah jika mengikuti pembelajaran konvensional. Dari alur pikir di atas, dapat dikatakan terdapat pengaruh interaksi 
antara model pembelajaran, yaitu pembelajaran matematika yang menggunakan model PBL terdapat hubungan yang kuat antara disposisi matematik dengan model pembelajara. Begitu juga dengan disposisi matematika rendah dipengaruhi oleh pembelajaran konvensional. Jadi model pembelajaran dan disposisi akan berdampak pada hasil belajar siswa.

Ketiga, hasil uji hipotesis ketiga berhasil menolak $\mathrm{H}_{0}$ dan menerima $\mathrm{H}_{1}$ yang berarti bahwa pada kelompok siswa yang memiliki disposisi matematika tinggi, terdapat perbedaan hasil belajar Matematika, antara siswa yang belajar dengan model pembelajaran PBL berpendekatan saintifik berbantuan media konkrit dengan siswa yang belajar dengan model pembelajaran konvensional berpendekatan saintifik yang dijadikan sampel penelitian.

Skor rata-rata hasil belajar Matematika siswa yang memiliki disposisi matematika tinggi yang mengikuti pelajaran dengan model pembelajaran PBL berpendekatan saintifik berbantuan media konkrit $=18,35$ dan skor rata-rata hasil belajar Matematika siswa yang mengikuti pelajaran dengan model pembelajaran konvensional

berpendekatan saintifik $=12,05$.

Keberhasilan proses pembelajaran tidak lepas dari ketepatan pemilihan model pembelajaran yang berdampak dan keampuan yang ingin dicapai dalam proses pembelajaran seperti LPB pembelajaran yang menggunakan masalah nyata (autentik) yang tidak terstruktur dan bersifat terbuka bagi siswa untuk mengembangkan keterampilan menyelesaikan masalah dan berpikir kritis sekaligus membangun pengetahuan baru. Berbeda dengan pembelajaran konvensional yang menjadikan masalah nyata sebagai penerapan konsep, PBL menjadikan masalah nyata sebagai pemicu bagi proses belajar pserta didik sebelum mengetahui konsep formal. Siswa secara kritis mengidentifikasi informasi dan strategi yang relevan serta melakukan penyelidikan untuk menyelesaikan masalah tersebut. Model pembelajaran PBL menekankan keaktifan peserta didik. Dalam hal ini, peserta didik dituntut aktif dalam memecahkan suatu masalah.Inti model PBL itu adalah masalah (problem).

Model pembelajaran berbasis masalah sebagai fasilitator guru membimbing siswa dimana ia diperlukan. Dengan model pembelajaran berbasis masalah siswa didorong untuk aktif, bisa memecahkan masalah sendiri dan berpikir kritis, sehingga dapat menemukan prinsip dan konsep berdasarkan apa yang disampaikan guru. Model PBL berpendekatan saintifik dengan bantuan media konkrit menghadapkan siswa pada situasi dimana ia bebas menyelidiki dan menarik kesimpulan, siswa dihadapkan pada situasi nyata, dimana ia bebas menemukan sesuatu yang baru. Pengajuan pertanyaan yang tepat oleh guru akan merangsang kreatifitas siswa dalam membantu mereka menemukan pengetahuan yang baru. Konsep belajar penemuan pada pembelajara matematika mengedepankan aspek berpikir kritis, aktif, logis, linier, dan teratur.

Sementara pada pembelajarn konvensional, guru memiliki kecendrungan sebagai pemegang otoritas pembelajaran. Komunikasi yang terjadi lebih banyak satu arah dan penggunaan metode caramah menjadi sangat dominan selama proses pembelajaran, siswa kurang aktif sehingga pembelajaran kurang kondusif. Pengembangan sosialisasi siswa, hubungan antar sesama siswa, pengembangan kemampuan berpikir kritis akan sangat terbatas. Komunikasi satu arah berdampak pada pengetahuan siswa yang hanya terbatas apa yang diberikan dan diketahui guru, siswa maupun dengan sumber belajarnya. Siswa kurang terlatih kemandiriannya sehingga siswa hanya akan belajar pada saat dikondisikan guru. Akibatnya, siswa tidak terbiasa dalam memperluas, memperdalam, dan memperkaya pengetahuannya yang pada gilirannya berpengaruh terhadap arendahnya hasil belajar siswa.

Berdasarkan uraian tersebut diatas, dapat dikatakan bahwa pada siswa yang memiliki disposisi tinggi, terdapat perbedaan hasil belajar matematika antara kelompok siswa yang mengikuti model 
pembelajaran PBL berpendekatan saintifik berbantuan media konkrit dan kelompok siswa yang mengikuti model pembelajaran konvensional.

Keempat, hasil uji hipotesis keempat berhasil menolak $\mathrm{H} 0$ dan menerima $\mathrm{H}_{1}$ yang menyatakan bahwa pada kelompok siswa yang memiliki disposisi matematika rendah, terdapat perbedaan hasil belajar Matematika antara siswa yang belajar dengan model pembelajaran PBL berbantuan media konkritdengan siswa yang belajar dengan model pembelajaran konvensional yang dijadikan sampel penelitian.

Skor rata-rata hasil belajar Matematika siswa yang memiliki disposisi matematika rendah yang mengikuti pelajaran dengan model pembelajaran PBL berbantuan media konkrit $=13,60$ dan skor rata-rata hasil belajar Matematika siswa yang mengikuti pelajaran dengan model pembelajaran konvensional $=14,80$ sehingga dapat disimpulkan bahwa untuk siswa yang memiliki disposisi matematika rendah, hasil belajar Matematika siswa yang mengikuti pelajaran dengan model pembelajaran konvensional lebih baik daripada siswa yang mengikuti pelajaran dengan model pembelajaran pembelajaran $\mathrm{PBL}$ berbantuan media konkrit.

Penerapan model pembelajaran PBL berpendekatan saintifik berbantuan media konkret berkontribusi secara signifikan dalam perbaikan proses pembelajaran, khususnya dalam menumbuhkan hasil belajar siswa dalam mengikuti pembelajaran. Penggunaan media realita dalam pembelajaran mampu

meningkatkan aktivitas belajar siswa dalm mengikuti pembelajaran. Dalam pembelajaran aktifitas siswa terdongkrak karena model pembelajaran berbasis masalah menuntut siswa untuk aktif, kreatif dalam memecahkan masalah, konsep dan prinsip yang disajikan guru dengan bimbingan guru. Keunggulan lainnya dapat melatih siswa untuk memberikan pendapat atau ide dalam pemecahan masalah.

Pembelajaran matematika dengan model PBL memberikan kesempatan kepada siswa untuk mengekspor kemampuannya sehingga menemukan ide untuk mecahkan masalah, mendorong siswa dalam melakukan evaluasi sendiri baik terhadap hasil maupun proses belajarnya, Ini artinya proses pembelajaran dengan model pembelajaran berbasis masalah memiliki kecendrungan dalam memecahkan suatu masalah dalam meningkatkan pembelajaran dengan model pembelajran berbasis masalah memiliki kecendrungan dalam meningkatkan pemahaman siswa terhadap materi pelajaran yang dipelajarinya. Model pembelajaran PBL berpendekatan saintifik berbantuan media konkret memungkinkan untuk menggairahkan dalam proses belajar, memotivasi siswa untuk berprestasi dan keinginan siswa untuk meningkatkan hasil belajar mereka.

Pada tahap ini terjadi disposisi matematika, siswa atas masalah yang diberikan oleh guru seperti menyatakan ulang kembali suatu konsep dengan cara bertanya jawab menggunakan bahasa sendiri dengan baik kepada guru ataupun siswa lainnya serta rasa percaya diri dan rasa ingintahu siswa dalam menyelesaikan masalah yang diberikan. Jelaslah bahwa pada tahap ini mendukung untuk mengembangkan kemampuan PBL berpendekatan saintifik berbantuan media konkrit dan disposisi matematis siswa menjadi lebih baik. Sementara pembelajaran konvensional selama proses pembelajaran, siswa kurang aktif sehingga pembelajaran berjalan monoton dan kurang menarik perhatian siswa. Hal ini dikarenakan pembelajaran konvensional dimulai dengan penyampaian materi dengan ceramah oleh guru, orientasi dan penyajian informasi yang berkaitan dengan konsep yang akan dipelajari, dilanjutkan dengan pemberian ilustrasi atau contoh soal oleh guru dan tanya jawab, sampai akhirnya guru merasa bahwa apa yang telah diajarkan dapat dimengerti oleh siswa. Guru cenderung memegang kontrol proses pembelajaran sehingga guru lebih aktif sementara siswa relatif pasif menerima dan mengikuti apa saja yang disampaikan oleh guru. 
Pembelajaran

konvensional cenderung menekankan penyampaian informasi yang bersumber pada buku teks, refrensi atau pengalaman pribadi dengan menggunakan teknik ceramah maupun diskusi, sehingga pengetahuan yang akan dipelajari siswa harus disajikan oleh guru perlu memberikan definisi dari konsep yang akan diterima siswa sehingga keberhasilan perubahan sikap dan perilaku peserta didik relatif sulit diukur.Ini berdampak pada kualitas pencapaian tujuan belajar yang telah ditetapkan relatif rendah karena guru sering hanya mengajar target waktu untuk menghabiskan target materi pembelajaran.

Berdasarkan uraian tersebut diatas, dapat dikatakan bahwa pada siswa yang memiliki disposisi rendah, terdapat perbedaan hasil belajar matematika antara kelompok siswa yang mengikuti model pembelajaran $\mathrm{PBL}$ berpendekatan saintifik berbantuan media konkrit dan kelompok siswa yang mengikuti model pembelajaran konvensional

Berdasarkan uraian tersebut, terlihat adanya keunggulan dan kelemahan masing-masing model pembelajaran, tergantung dari tingkat disposisi matematika siswa. Sehingga dalam proses pembelajaran sebaiknya guru mempertimbangkan kondisi siswa tersebut. Siswa yang memiliki disposisi matematika tinggi lebih baik diberikan pelajaran dengan menggunakan model pembelajaran PBL berpendekatan saintifik berbantuan media konkrit, sementara siswa yang memiliki disposisi matematika rendah lebih baik diberikan pelajaran dengan menggunakan model pembelajaran konvensional berpendekatan saintifik.

\section{PENUTUP}

Berdasarkan analisis data seperti yang telah dipaparkan pada bagian sebelumnya, diperoleh temuan sebagai berikut.

1. Terdapat perbedaan hasil belajar Matematika antara siswa yang belajar dengan model pembelajaran PBL berpendekatan saintifik berbantuan media konkrit dengan siswa yang belajar dengan model pembelajaran konvensional berpendekatan saintifik di kelas III SD Gugus VI Sukawati. Hasil belajar Matematika siswa yang mengikuti pelajaran dengan model pembelajaran $\mathrm{PBL}$ berpendekatan saintifik dengan bantuan media konkrit lebih baik daripada hasil belajar Matematika siswa yang mengikuti pelajaran dengan model pembelajaran konvensional berpendekatan saintifik.

2. Terdapat pengaruh interaksi antara model pembelajaran dan disposisi matematika terhadap hasil belajar Matematika. Untuk siswa yang memiliki disposisi matematika tinggi, hasil belajar Matematika siswa yang mengikuti pelajaran dengan model pembelajaran $\mathrm{PBL}$ berpendekatan saintifik berbantuan media konkrit lebih baik daripada model pembelajaran konvensional berpendekatan saintifik. Sebaliknya, untuk siswa yang memiliki disposisi matematika rendah, hasil belajar Matematika siswa yang mengikuti pembelajaran dengan model pembelajaran konvensional berpendekatan saintifik lebih baik daripada model pembelajaran PBL berpendekatan saintifik berbantuan media konkrit.

3. Pada kelompok siswa yang memiliki disposisi matematika tinggi, terdapat perbedaan hasil belajar Matematika, antara siswa yang belajar dengan model pembelajaran

PBL berpendekatan saintifik berbantuan media konkrit dengan siswa yang belajar dengan model pembelajaran

konvensional berpendekatan saintifik. Hasil belajar siswa yang memiliki disposisi matematika tinggi yang mengikuti pelajaran dengan model pembelajaran $P B L$ berpendekatan saintifik berbantuan media konkrit lebih baik daripada siswa yang mengikuti pelajaran dengan model pembelajaran konvensional berpendekatan saintifik.

4. Pada kelompok siswa yang memiliki disposisi matematika rendah, terdapat perbedaan hasil belajar Matematika 
antara siswa yang belajar dengan model pembelajaran PBL

berpendekatan saintifik berbantuan media konkrit dengan siswa yang belajar dengan model pembelajaran konvensional berpendekatan saintifik. Hasil belajar siswa yang memiliki disposisi matematika rendah yang mengikuti pembelajaran dengan model pembelajaran konvensional berpendekatan saintifik lebih baik daripada siswa yang mengikuti pelajaran dengan model pembelajaran PBL berpendekatan saintifik dengan bantuan media konkrit.

Berdasarkan temuan di atas, dapat disimpulkan bahwa model pembelajaran PBL berpendekatan saintifik dengan bantuan media konkrit berpengaruh terhadap hasil belajar Matematika ditinjau dari disposisi matematika pada siswa kelas III SD Gugus VI Sukawati.

\section{DAFTAR RUJUKAN}

Candiasa, I M. 2010. Statistik Univariat dan Bivariat Disertai Aplikasi SPSS. Singaraja: Undiksha Press.

Kamarianto, Noviana.E dan, Alpusari.M2018. Penerapan Model Pembelajaran Probleam Basad Learning untuk meningkatkan Hasil Belajar IPS Siswa Kelas IV SD Negeri 001 Kec. Sinaboi (Jurnal Dillne Mahasiswa, Vol.5, No. 1 dinduh pada http://Jom.uri.ac.id) diunduh tanggal 22 Januari 2019.

Kippatrick, Swafford, dan Findell, (2001). Adding It Up: Helping Children Learn mathematics. National Acdemy Press.

Kurnia, U.,Rifai,H., \&Nurhayati.(2015). Efektivitas Penggunaan Gambar Pada Brosur Dalam Modem Pembelajaran Problem Based Learning untuk Meningkatkan Hasil Belajar FisikaKelas SMAN 5 Padang. Pilar of Physics Education,6(3),105112.

Lidinillah, D. A. M. 2013. Pembelajaran Berbasis Masalah (Problem Basad
Learning).

(Online),

(http://file.upi.edu/Direktori/KD-

Tasikmalaya/Dindin_Abdul_Muiz_Lid inillah_(KD-Tasikmalaya)

$197901132005011003 / 132313548 \%$

20\%20dindin\%20abdul\%20muiz\%2

0

lidinillah/Problem\%20Based\%20Lea r ning.pdf), diakses23 Juni 2015.

Mahmudi, A. (2010). Tinjauan asosiasi antarakemampuan pemecahan masalah matematis dan disposisi matematis. (online).Dikes dari:http://staf.uny.ac.id/sites/default/ files/penelitian/ali\%20Mahmudi, $\% 20$ S.Pd,\%20M.Pd,\%20Dr./Makalah\%2 012\%20LSM\%20April\%202010\%20 _Asosiasi\%20KPMM\%20dan\%20Di s posisi\%20Matematis_pdf.

Rasyid, H dan Mansur. 2007. Penilaian Hasil Belajar. Bandung: CV Wacana Prima.

Royhana, N.S.2016. Pengaruh Metode Pembelajaran

Terhada

$\mathrm{p}$

Kemampuan

n Matematika Ditinjau dari Efikasi

Diri (Jurnal Pendidikan Dasar UNJ, P- ISSN : 20186-7433,e-ISSN: 2549-

5801 diunduh pada htt:// Jurnal UNJK.ac.id) dinduh. Tanggal 28 Februari 2019. 